\title{
EFFECTS OF OCCUPATIONAL SAFETY PRACTICE AND SUPERVISORY ENFORCEMENT ON THE SAFETY REPORTING: EXPLORATORY FACTOR ANALYSIS
}

\author{
Akmal Wani Sulong ${ }^{1}$ and Azmi Hassan ${ }^{1}$ \\ ${ }^{1}$ Faculty of Medicine, Universiti Sultan Zainal Abidin, Terengganu, Malaysia. \\ Corresponding author: Akmal Wani Sulong \\ Email: akmalwani@gmx.com
}

\begin{abstract}
This paper analyses the construct validity and reliability of a new developed questionnaire measuring the effects of the occupational safety practice and supervisory enforcement on the safety and health reporting among the oil palm labours. The exploratory factor analysis (EFA) was conducted to determine the underlying dimensions between variables and refine the proposed theory. The EFA was performed using the statistical analysis software SPSS. The questionnaire for all constructs was designed by adopting and customizing questionnaires from previous studies and reviewed by the language, content and statistical experts before it was administered on 100 oil palm Federal Land Development Authority (FELDA) labours. All of the variables passed the Bartlett's Test of Sphericity ( $p$-value $<0.05)$ and the measure of sampling adequacy using Kaiser-Meyer-Olkin (KMO > 0.60). The Cronbach's Alpha value for the occupational safety practices for Organizational Safety Support (OSS), Safety Knowledge and Emergency Trainings (SKET), Compliance to Safety and Health Regulations (CSHR), and the Safety Procedures and Risk Management (SPRM) components were 0.957, 0.957, 0.940 and 0.936 respectively. The Cronbach's Alpha for the supervisory enforcement construct was 0.930, while the value for safety reporting was 0.976 for component 1 and 0.936 for component 2. The validity and reliability of the questionnaires to assess the effect of occupational safety practice and the supervisory enforcement on the safety and health reporting among the Malaysian oil palm labours is confirmed.
\end{abstract}

Keywords: Safety and health practice, Supervisory enforcement, Injury reporting, Reliability, Validity, Oil palm labours

\section{INTRODUCTION}

Studies around the world have proven that the rate of injuries among the agricultural employees is still at an alarming rate despite trainings, new technologies, prevention programmes, and improved safety and health policies ${ }^{1-3}$. As in Malaysia, the recent statistic provided by the Social Security Organization (SOCSO) has shown that the agricultural injuries have increased from 1852 cases in 2015 to 1946 cases in 2016 ${ }^{4,5}$. According to the Department of Occupational Safety and Health (DOSH), agriculture is the third contributor to the accident statistic with 366 nonpermanent disability cases, nine permanent disabilities, and 18 deaths since January until October $2017^{6}$.

As one of the highest contributors among the agriculture sector to the Malaysia's Gross Domestic Product (GDP), a number of studies focusing on the safety and health issues among the oil palm labours were available. However, no published articles were found to study the accident reporting among the oil palm labours. Common issues that were previously discussed included the ergonomics and musculoskeletal disorders (MSDs) ${ }^{7-13}$, safety and health knowledge, attitude, and practice (KAP) ${ }^{14,15}$, as well as the safety and health in the oil palm mills ${ }^{16-18}$.

The concern lies in the differences of accident data provided by SOCSO and DOSH which indicates the underreporting. Researchers have found that the underreporting is becoming more prevalent among employees around the world ${ }^{19-21}$. Common reasons include minor injuries, self-blamed, selfemployed, refuse to miss the working time, and time-consuming process ${ }^{21}$, individual fear ${ }^{22}$, worry of others' perceptions ${ }^{21,22}$, perceived nonattributable injury and lack of knowledge $\mathrm{e}^{21,23}$, as well as having multiple categories and lack of information on injury category ${ }^{23}$. Production demands and cultural factors were also found as the excuse for the workers to not report any safety and health-related issues to their supervisor or employer ${ }^{24}$. Other factors include poor safety climate, job uncertainty and moral disconnection ${ }^{25-27}$.

Previous studies suggested that the accident reporting could be improved by the supervisory enforcement ${ }^{28-31}$. Enforcing safety supervision and reporting workplace accidents are vital to prevent the ailing individual from being left untreated, and ensure the organization to recognize and fix 
the root cause of the accident to avert any possibilities of recurring cases $^{27}$. Furthermore, the accident underreporting could jeopardize the effectiveness of government's intervention programmes since they are planned according to the accident data ${ }^{32}$.

Additionally, the safety and health practice was found correlated with the safety reporting system and the supervision was highly significant with the employees' efficacy ${ }^{33}$. The organizational safety and health practices encompassing safety procedures and risk management, safety and health rules, first aid support and training, occupational accident prevention, and organizational safety support were also found to positively affect the organizational commitment ${ }^{34}$. This is crucial in ensuring the successfulness of the overall safety and health systems at their organization, which includes the accident reporting. Therefore, the current study predicts that the occupational safety and health practice along with supervisory enforcement could improve the safety and health reporting among the oil palm labours. This paper aims to develop a valid and reliable questionnaire to determine the effects of organizational safety and health practice as well as the supervisory enforcement on the safety and health reporting among the oil palm labours.

\section{METHODS}

This study was conducted with a sample of 100 fresh fruit harvesters at eight oil palm plantations located in Terengganu, Malaysia. The respondents were recruited to fill up the questionnaires consisting the demographic background of the respondents, the safety and health practice in their workplace, supervisory enforcement, and the safety and health reporting which measure their reporting knowledge, attitude, and practice.

The questionnaire was developed by stages. Firstly, the questions for the demographic background were developed based on the results of previous studies regarding contributing factors towards workplace accidents, such as gender, age, race, work experience, income, and educational background ${ }^{35-37}$. The next part of the questionnaire which was the organizational safety practice was developed by adopting and customizing the previous questionnaire ${ }^{34}$, meanwhile, the supervisory enforcement questions were adopted and modified from the scales used in previous study ${ }^{30}$. Finally, the safety and health reporting questions were developed from the combinations of OSHA Act 1954 statements and our own premonition. All these questions were then reviewed by two professional safety and health officers and a professor in statistical analysis. The feedback from all experts was then reviewed and the corrections were made. Next, the amended questionnaires were translated into Bahasa Malaysia by two bilingual experts, which later were back-translated into English by a different translator. Since this study was intended to be carried out using Bahasa Malaysia, the backward translation was required to make sure that the questions carried the same meaning with the original questions without using the same sentences. The questions were then finalized through a group discussion with two lecturers from the safety and health background before it was distributed to the respondents.

The scoring for the safety and health practice, supervisory enforcement, and safety reporting constructs were positive type items using interval scales of " 1 " for "strongly disagree" to "10" for "strongly agree". By using the interval scale of 1 to 10 , the respondents were presumably to give more reliable answers and therefore serve a more promising success in construct validity ${ }^{38}$. The data entry and all statistical analysis for this study were conducted using the IBM's Statistical Packages for the Social Sciences (SPSS) Version 23. The exploratory factor analysis using Principal Component Analysis (PCA) method and Varimax Rotation have been executed for all items of each construct. The reliability of the items to measure their component were then evaluated by computing the Cronbach's Alpha. The Cronbach's Alpha value of 0.6 or higher for a component denotes that the items under that component provides a reliable amount of internal consistency ${ }^{39}$.

\section{RESULTS}

\section{Exploratory factor analysis for Occupational} Safety and Health Practice construct

The occupational safety practice construct in this study was arranged according to the questionnaires adapted from the previous study ${ }^{34}$. It consisted of thirty items which were arranged to five components as proposed in the original article, namely the safety procedures and risk management (SPRM), safety and health rules (SAHR), first-aid supports and training (FAST), occupational hazard prevention (OHP), and organizational safety support (OSS). The Bartlett's Test of Sphericity for this construct was significant ( $p$-value $<0.05$ ), and the measure of sampling adequacy by Kaiser-Meyer-Olkin (KMO) was 0.916 . The factor analysis converted the items into four separate dimensions with eigenvalues exceeding 1.0 as shown in Table 1. The table also shows the factor loading for all thirty items according to their assigned components. Additionally, the results revealed that for component 1, 2, 3 and 4, the Cronbach's Alpha were $0.957,0.957,0.940$, and 0.936 respectively. 
Table 1a Rotated component matrix, factor loading, and Cronbach's Alpha for Occupational Safety Practice construct

\begin{tabular}{|c|c|c|c|c|c|}
\hline \multirow[t]{2}{*}{ Safety and Health Practice Item } & \multirow[t]{2}{*}{ Mean (SD) } & \multicolumn{4}{|c|}{ Safety and Health Practice Component } \\
\hline & & $\begin{array}{c}\text { Component } \\
1\end{array}$ & $\begin{array}{c}\text { Component } \\
2\end{array}$ & $\begin{array}{c}\text { Component } \\
3\end{array}$ & $\begin{array}{c}\text { Component } \\
4\end{array}$ \\
\hline \multicolumn{6}{|l|}{$\begin{array}{l}\text { Safety Procedures and Risk } \\
\text { Management (SPRM) }\end{array}$} \\
\hline $\begin{array}{l}\text { Any changes in job distribution is } \\
\text { informed to employees }\end{array}$ & $8.78(1.83)$ & & & & 0.727 \\
\hline $\begin{array}{l}\text { Supervisors/ employers inform to } \\
\text { the workers about our } \\
\text { occupational risk }\end{array}$ & $8.79(1.86)$ & & & & 0.719 \\
\hline $\begin{array}{l}\text { My working procedure/ } \\
\text { arrangement follows the } \\
\text { working procedure prepared by } \\
\text { the employers }\end{array}$ & $8.79(1.83)$ & & & & 0.823 \\
\hline $\begin{array}{l}\text { I am knowledgeable about every } \\
\text { working procedure }\end{array}$ & $8.46(2.00)$ & & & & 0.718 \\
\hline $\begin{array}{l}\text { The number of workers are } \\
\text { sufficient to all work completion }\end{array}$ & $8.34(2.18)$ & & 0.801 & & \\
\hline $\begin{array}{l}\text { The number of work assigned to } \\
\text { workers are balanced } \\
\text { Safety and Health Regulations } \\
\text { (SAHR) }\end{array}$ & $8.25(2.18)$ & & 0.759 & & \\
\hline $\begin{array}{l}\text { The time allocated for work is not } \\
\text { burdensome }\end{array}$ & $8.74(1.64)$ & & & & \\
\hline I have enough rest time & $8.47(1.93)$ & & & 0.718 & \\
\hline $\begin{array}{l}\text { Health and safety regulations are } \\
\text { practical }\end{array}$ & $8.71(1.69)$ & & & 0.704 & \\
\hline $\begin{array}{l}\text { I abide by the rules even though } \\
\text { my working schedule is tight }\end{array}$ & $8.84(1.70)$ & & & 0.662 & \\
\hline $\begin{array}{l}\text { I have undergone health check- } \\
\text { ups before being employed }\end{array}$ & $8.97(1.88)$ & & & & \\
\hline $\begin{array}{l}\text { I go for regular health check-ups } \\
\text { since I have been employed }\end{array}$ & $8.44(2.27)$ & & & & \\
\hline $\begin{array}{l}\text { Employers/ supervisors remove } \\
\text { things that are hazardous to my } \\
\text { health and safety from the work } \\
\text { place }\end{array}$ & $8.67(1.95)$ & & & 0.634 & \\
\hline $\begin{array}{l}\text { Employer/ supervisors are } \\
\text { concerned about the disabled's } \\
\text { and older workers' needs. } \\
\text { First-Aid Support and Training } \\
\text { (FAST) }\end{array}$ & $8.74(1.78)$ & 0.668 & & & \\
\hline $\begin{array}{l}\text { Fast aid treatment is available at } \\
\text { workplace }\end{array}$ & $8.72(1.93)$ & & 0.633 & & \\
\hline $\begin{array}{l}\text { I am trained about things that are } \\
\text { hazardous to my health and } \\
\text { safety. }\end{array}$ & $8.60(1.95)$ & & 0.725 & & \\
\hline $\begin{array}{l}\text { I am provided with hygiene and } \\
\text { health trainings }\end{array}$ & $8.61(2.05)$ & & 0.775 & & \\
\hline $\begin{array}{l}\text { I am provided with first aid } \\
\text { trainings. }\end{array}$ & $8.49(2.21)$ & & 0.820 & & \\
\hline
\end{tabular}


Table 2b Rotated component matrix, factor loading, and Cronbach's Alpha for Occupational Safety Practice construct

\begin{tabular}{|c|c|c|c|c|c|}
\hline \multirow[t]{2}{*}{ Safety and Health Practice Item } & \multirow[t]{2}{*}{ Mean (SD) } & \multicolumn{4}{|c|}{ Safety and Health Practice Component } \\
\hline & & $\begin{array}{c}\text { Component } \\
1\end{array}$ & $\begin{array}{l}\text { Component } \\
2\end{array}$ & $\begin{array}{c}\text { Component } \\
3\end{array}$ & $\begin{array}{c}\text { Component } \\
4\end{array}$ \\
\hline $\begin{array}{l}\text { Occupational Hazard Prevention } \\
(\text { OHP) }\end{array}$ & & & & & \\
\hline $\begin{array}{l}\text { am provided with safety } \\
\text { equipment such as goggles, } \\
\text { safety helmets, boots, gloves, } \\
\text { masks, and suits (jumpsuit). }\end{array}$ & $8.91(1.85)$ & & & 0.765 & \\
\hline $\begin{array}{l}\text { Only trained and fully equipped } \\
\text { workers are allowed to access } \\
\text { dangerous and risky places }\end{array}$ & $8.61(2.12)$ & & & & \\
\hline $\begin{array}{l}\text { Workers in risky areas are } \\
\text { always supervised to make sure } \\
\text { they follow the right and safe } \\
\text { procedures }\end{array}$ & $8.85(1.79)$ & & & & \\
\hline $\begin{array}{l}\text { Workers' mistakes and } \\
\text { shortcomings are disclosed } \\
\text { during internal audit }\end{array}$ & $8.62(1.78)$ & & & & \\
\hline $\begin{array}{l}\text { My workplace has sufficient } \\
\text { lighting and room for movement }\end{array}$ & $9.00(1.55)$ & & & & \\
\hline $\begin{array}{l}\text { My workplace has designated } \\
\text { area for garbage. }\end{array}$ & $8.66(1.96)$ & & & & \\
\hline $\begin{array}{l}\text { My workplace provides health and } \\
\text { safety equipment like fire } \\
\text { extinguishers or water hoses. }\end{array}$ & $8.60(2.18)$ & 0.631 & & & \\
\hline $\begin{array}{l}\text { Organizational Safety Support } \\
\text { (OSS) }\end{array}$ & & & & & \\
\hline $\begin{array}{l}\text { Employers provide sufficient } \\
\text { treatment and within appropriate } \\
\text { timing. }\end{array}$ & $8.90(1.71)$ & 0.605 & & & \\
\hline $\begin{array}{l}\text { I am provided with sufficient } \\
\text { resting period before returning } \\
\text { to work after sustaining injury. }\end{array}$ & $9.00(1.58)$ & 0.800 & & & \\
\hline $\begin{array}{l}\text { The employers compensate } \\
\text { workers who sustained injuries/ } \\
\text { involved in an accident. }\end{array}$ & $8.89(1.80)$ & 0.794 & & & \\
\hline $\begin{array}{l}\text { The employers abide by the } \\
\text { working health and safety } \\
\text { regulations }\end{array}$ & $8.93(1.71)$ & 0.763 & & & \\
\hline $\begin{array}{l}\text { The employers keep the privacy } \\
\text { of all workers' medical record }\end{array}$ & $9.04(1.50)$ & 0.782 & & & \\
\hline Eigenvalue & & 19.553 & 1.870 & 1.334 & 1.199 \\
\hline Explained Variance (\%) & & 24.209 & 20.698 & 18.695 & 16.248 \\
\hline Cumulative Variance (\%) & & 24.209 & 44.907 & 63.602 & 79.851 \\
\hline Cronbach's Alpha ( $\mathrm{N}$ of items) & & $0.957(8)$ & $0.957(6)$ & $0.940(5)$ & $0.936(4)$ \\
\hline
\end{tabular}

*Items failed to load in bold.

Exploratory factor analysis for Supervisory Enforcement construct

The supervisory enforcement (SE) construct was prepared using five items. The Bartlett's Test of Sphericity for this construct was also significant (p-value < 0.05), and the measure of sampling adequacy by KMO was 0.834 which passed the minimum value of 0.6 . The supervisory enforcement construct was found to measure using one component of five items with a cumulative of $80.064 \%$. Correspondingly, the factor loading of all items passed the minimum value of 0.6 by ranging from 0.818 to 0.928 .

Ensuing those results, the reliability of the items to measure supervisory enforcement construct was evaluated using the Cronbach's Alpha value. Table 2 shows that the Cronbach's Alpha for the items was 0.930 . 
Table 3 Rotated component matrix, factor loading, and Cronbach's Alpha for Supervisory Enforcement construct

\begin{tabular}{lll}
\hline Item Wording & Mean (SD) & Factor Loading \\
\hline $\begin{array}{l}\text { Supervisors/ employers listen to my comments regarding } \\
\text { the right and safe working procedure }\end{array}$ & $8.670(1.985)$ & 0.910 \\
$\begin{array}{l}\text { Supervisors/ employers put effort in coming up with a } \\
\text { correct and safe working procedure }\end{array}$ & $8.680(2.093)$ & 0.928 \\
$\begin{array}{l}\text { Supervisors/ employers reward those who abide by the } \\
\text { rules }\end{array}$ & $7.700(2.717)$ & 0.818 \\
$\begin{array}{l}\text { Supervisors/ employers warn employees who do not } \\
\text { abide by the health and safety regulations at work. }\end{array}$ & $8.850(1.930)$ & 0.900 \\
$\begin{array}{l}\text { Supervisors/ employers punish employees who repeat } \\
\text { their offences. }\end{array}$ & $8.600(2.151)$ & 0.914 \\
$\begin{array}{l}\text { Eigenvalue } \\
\text { Explained Variance (\%) }\end{array}$ & & 4.003 \\
$\begin{array}{l}\text { Cumulative Variance (\%) } \\
\text { Cronbach's Alpha (N of items) }\end{array}$ & 80.064 \\
\hline
\end{tabular}

Exploratory factor analysis for Safety and Health Reporting construct.

The safety reporting construct was arranged to three components namely reporting knowledge (RK), attitude (RA), and practice (RP) containing of 23 items. The Bartlett's Test of Sphericity for this construct was significant ( $p$-value $<0.05)$, and the measure of sampling adequacy by KMO was 0.909 , which indicates that the data was satisfactory for the next step in the exploratory factor analysis. The factor analysis for this construct extracted two dimensions with the eigenvalues exceeding 1.0. The factor loading of all these items under each component was shown in Table 3. The values were satisfactorily surpassed the minimum value of 0.6 , ranging from 0.612 to 0.907 . Finally, as seen in the Table 3 , the Cronbach's alpha for the items were 0.976 for component 1 and 0.936 for component 2 .

\section{DISCUSSION}

In this paper, we describe the data reduction procedure in factor analysis and reliability study of a new instrument in measuring the influence of occupational safety practice and supervisory enforcement on the workplace safety reporting. To the best of our knowledge, this study was the first to explore this topic among the oil palm labours.

From this study, we discovered that there were four distinct factors or components for the occupational safety practice construct. Based on the new arrangement, the four components were named Organizational Safety Support (OSS), Safety Knowledge and Emergency Trainings
(SKET), Compliance to Safety and Health Regulations (CSHR), and the Safety Procedures and Risk Management (SPRM) for component 1, component 2, component 3 , and component 4 respectively. The changes from the original paper could be due to the different types of respondents for both studies. Nevertheless, all items match the measurement scales of safety practices in previous study ${ }^{40}$. All components were also considered as strong predictors for voicing out, reporting injuries, and the job performance ${ }^{41}$. They were also described as important factors in improving employees' behavioural safety compliance which could increase the safety performance at the workplace ${ }^{42}$. Most importantly, the reliability of all the components to measure safety practice construct was demonstrated by the high value of the Cronbach's alpha.

Instantaneously, the factor analysis showed that the supervisory enforcement construct in this study was defined by one factor involving five items. The factor loading of all items were higher than 0.80 , indicating that all items were statistically significant to measure the construct. The results were in agreement with previous study in which the items were used as scales in measuring safety supervision and enforcement ${ }^{29,30,43}$. After all, the Cronbach's alpha for this construct was high (0.93), therefore confirms the reliability of the items. 
Table 4 Rotated component matrix, factor loading, and Cronbach's Alpha for Safety Reporting construct Item Wording Mean (SD) Factor Loading Component 1

Component 2

\begin{tabular}{|c|c|c|c|}
\hline \\
\hline $\begin{array}{l}\text { To the best of my knowledge... } \\
\text { Reporting any occupational injuries, accidents, and } \\
\text { diseases are very recommended by the Department of } \\
\text { Occupational Safety and Health Malaysia. }\end{array}$ & $8.720(1.975)$ & 0.692 & \\
\hline $\begin{array}{l}\text { I have to report any injury, accident, and disease } \\
\text { endured to employers / supervisors. }\end{array}$ & $9.020(1.723)$ & 0.880 & \\
\hline $\begin{array}{l}\text { I have to report any injury, accident, and disease } \\
\text { endured by a colleague to employers / supervisors }\end{array}$ & $8.960(1.729)$ & 0.872 & \\
\hline $\begin{array}{l}\text { Light injury such as small wounds or sprains have to be } \\
\text { reported to employers/ supervisors }\end{array}$ & $8.300(2.163)$ & & 0.612 \\
\hline $\begin{array}{l}\text { Bodily discomforts (neck, shoulder, arm, lower back, } \\
\text { knee) have to be reported to employers/ supervisors }\end{array}$ & $7.990(2.355)$ & & 0.798 \\
\hline $\begin{array}{l}\text { Usage of poison, or dangerous or banned chemicals } \\
\text { have to be reported to employers/ supervisors }\end{array}$ & $9.000(1.614)$ & 0.748 & \\
\hline $\begin{array}{l}\text { Usage of broken equipment or machines have to be } \\
\text { reported to employers/ supervisors }\end{array}$ & $9.140(1.457)$ & 0.766 & \\
\hline $\begin{array}{l}\text { Unsafe working practices need to be reported to } \\
\text { employers/ supervisors }\end{array}$ & $8.860(2.005)$ & 0.786 & \\
\hline $\begin{array}{l}\text { Incomplete personal protective equipment (PPE) has to } \\
\text { be reported to supervisors/ employers }\end{array}$ & $8.870(1.884)$ & 0.735 & \\
\hline $\begin{array}{l}\text { I have to report to supervisors / employers if I am } \\
\text { depressed due to occupational demand }\end{array}$ & $8.130(2.650)$ & & 0.631 \\
\hline $\begin{array}{l}\text { Reporting occupational hazards, risks, accidents, and } \\
\text { diseases... }\end{array}$ & & & \\
\hline Is a responsibility to all employees & $8.870(1.931)$ & 0.820 & \\
\hline $\begin{array}{l}\text { Can reduce the rate of injuries, accidents, and } \\
\text { diseases among employees in the future }\end{array}$ & $8.960(16.81)$ & 0.907 & \\
\hline $\begin{array}{l}\text { Enables the employer to prepare better safety and } \\
\text { health facilities in the future. }\end{array}$ & $8.820(1.882)$ & 0.862 & \\
\hline Eases employees in getting treatment & $8.970(1.738)$ & 0.824 & \\
\hline $\begin{array}{l}\text { Has to be done as soon as possible upon enduring } \\
\text { injuries, accidents, or diseases }\end{array}$ & $9.080(1.692)$ & 0.887 & \\
\hline I report to supervisors/ employers whenever... & & & \\
\hline I suffer from minor injuries while doing a task & $7.530(2.710)$ & & 0.841 \\
\hline $\begin{array}{l}\text { I have body parts discomfort (neck / shoulder / back / } \\
\text { lower back / knee) while doing a task }\end{array}$ & $8.080(2.228)$ & & 0.824 \\
\hline $\begin{array}{l}\text { I suffer from poisoning after using pesticides or } \\
\text { chemicals at work place. }\end{array}$ & $8.900(1.856)$ & 0.706 & \\
\hline I find mislabeled or improperly contained chemicals & $8.720(1.954)$ & & \\
\hline Tools or equipment used are frequently broken & $9.010(1.592)$ & 0.646 & \\
\hline The work place is a mess / hinders movement & $8.490(2.298)$ & & 0.710 \\
\hline Feel unfit to continue working on a task & $8.710(2.051)$ & & 0.794 \\
\hline Feel depressed due to work & $8.140(2.686)$ & & 0.736 \\
\hline Eigenvalue & & 15.230 & 2.031 \\
\hline Explained Variance (\%) & & 66.216 & 8.830 \\
\hline Cumulative Variance (\%) & & 66.216 & 75.046 \\
\hline Cronbach's Alpha ( $\mathrm{N}$ of items) & & $0.976(14)$ & $0.936(8)$ \\
\hline
\end{tabular}

*Items failed to load in bold.

One of the noteworthy findings in this study was there were two factors measuring safety reporting. For the first component, the factor analysis has regrouped all safety attitude items with the items for safety knowledge, as well as the knowledge to report, and the practice of reporting self-injuries, colleagues' injuries, unsafe work procedures, usage of dangerous chemicals, and as the usage of broken tools or equipment. Thus, the first component was

viewed to include major issues such as responsibilities towards safety reporting, urgency of reporting, and reporting serious safety matters which almost certainly cause missing work time. On the other hand, the knowledge to report and the practice of reporting minor injuries, MSDs, 
feeling unfit, having task related depressions, and messy work areas were assembled into another component. The second component therefore embraced the safety and health issues which were considered as less significant and may not cause the missing work time. The results were concurring with the previous studies that the practice of reporting safety and health issues were influenced by the gravity of the accident or injury ${ }^{20,21}$. Accordingly, the two components were renamed as major reporting and minor reporting to compliment the items which were sorted into the same components. Despite that, the factor loading for most of the items were higher than 0.60 , with one item from the reporting attitude failed to load in any of both components, hence were dropped for future analysis (CFA).

\section{Strength and Limitations}

The result of this study was deemed reliable due to its large number of minimum 100 respondents However, since this study was an exploratory factor analysis study, the variables used need to be confirmed by a Confirmatory Factor Analysis (CFA) involving a bigger population. Once the CFA was done, the data can be used for further analysis on the topic of this study.

\section{CONCLUSION}

Concisely, this study has managed to reduce the data for future analysis. The results implied that the new developed questionnaire demonstrates an adequate measure of each construct to study the effects of the occupational safety practice, and supervisory enforcement on the safety reporting among the oil palm labours. The content and construct validity has been confirmed and the internal consistency reliability was fit for future study.

\section{Acknowledgements}

This study was supported by the UnisZA Human Research Ethics Committee (UHREC/2016/2/007). The authors thank all participants who were involved in the collection of the data used in this study.

\section{Conflict of interest}

The authors declare no potential conflict of interest.

\section{REFERENCES}

1. Robert K, Elisabeth Q, Josef B. Analysis of occupational accidents with agricultural machinery in the period 2008-2010 in Austria. Saf Sci [Internet]. 2015 Feb [cited 2015 Feb 4];72:319-28. Available from: http://www.sciencedirect.com/science/ article/pii/S0925753514002367

2. Kang S-K, Kwon O-J. Occupational injury statistics in Korea. Saf Health Work [Internet]. 2011 Mar [cited 2015 Mar
11];2(1):52-6. Available from: http://www.sciencedirect.com/science/ article/pii/S2093791111210072

3. Quendler E, Boxberger J. Near accidents with agricultural vehicles, machinery and equipment in Austria in the year 2013. 2015; 17(1):141-58.

4. Kementerian Sumber Manusia. Statistik Pekerjaan dan Perburuhan Siri 7 Bil. 1/2016. Malaysia; 2016.

5. Kementerian Sumber Manusia. Statistik Pekerjaan dan Perburuhan Siri 11 Bil. 1/2017 [Internet]. Malaysia; 2017. Available from: http://myhos.mohr.gov.my/ebook/istati stik1_2017/index.html\#p=1

6. Department of Occupational Safety And Health. Occupational Accidents Statistics by Sector Until October 2017 [Internet]. Department of Occupational Safety And Health. 2017. Available from: http://www.dosh.gov.my/index.php/en/ occupational-accident-statistics/by-secto

7. Ng YG, Bahri S, Tamrin M, et al. The prevalence of musculoskeletal disorder and association with productivity loss: a preliminary study among labour intensive manual harvesting activities in oil palm plantation. Ind Health [Internet]. 2014;52:78-85. Available from: http://www.ncbi.nlm.nih.gov/pubmed/2 4292878

8. Mokhtar MM, Deros BM, Sukadarin EH. Evaluation of Musculoskeletal Disorders Prevalence during Oil Palm Fresh Fruit Bunches Harvesting Using RULA. Adv Eng Forum [Internet]. 2013;10:110-5. Available from: http://www.scientific.net/AEF.10.110

9. Nawi NSM, Deros BM, Rahman MNA, Sukadarin EH, Nordin N. Malaysian oil palm workers are in pain: Hazards identification and ergonomics related problems. Malaysian J Public Heal Med. 2016;16:50-7.

10. Ng YG, Bahri MTS, Irwan Syah MYI, Mori I, Hashim Z. Ergonomics observation: Harvesting tasks at oil palm plantation. $J$ Occup Health [Internet]. 2013;55(5):40514. Available from: http://www.scopus.com/inward/record. url?eid=2-s2.084886638511\&partnerID=tZOtx3y1

11. Nur Syazwani MN, Baba MD, Mohd Nizam $A R$, et al. Ergonomic risk assessment of manual handling tools by oil palm collectors and loaders. Malaysian J Public 
Heal Med. 2016;16:56-60.

12. Sukadarin $\mathrm{EH}$, Deros $\mathrm{BM}$, Ghani JA, Ismail AR, Mokhtar MM, Mohamad D. Investigation of Ergonomics Risk Factors for Musculoskeletal Disorders among Oil Palm Workers Using Quick Exposure Check (QEC). Adv Eng Forum [Internet]. 2013;10:103-9. Available from: http://www.scientific.net/AEF.10.103

13. Shan $\mathrm{CL}$, Adon $\mathrm{MY}$ Bin, Rahman $\mathrm{ABA}$, Hassan STS, Ismail K Bin. Prevalence of Neck Pain and Associated Factors with Personal Charateristics, Physical Workloads and Pyschosocial Among Male Rubber Workers in FELDA Settlement Malaysia. Glob J Health Sci [Internet]. 2011;4(1):94-104. Available from: http://www.ccsenet.org/journal/index. $\mathrm{php} / \mathrm{gjhs} /$ article/view/12774

14. Zolkifli NZ, Mohd Tamrin SB, Guan NY, et al. Knowledge, attitude and practice on the usage of safety helmet among oil palm harvesters. Malaysian J Public Heal Med. 2016;1(Suppl.1):44-9.

15. Mior SNM, Leman AM, Baharudin MR, Masripan R, Faazir MT, Ifwat M. A Preliminary Study of Knowledge, Attitude and Practices of Pesticide Use Among Oil Palm Workers in Johor. In: 2nd International Conference on Green Design and Manufacture 2016 (IConGDM 2016). 2016.

16. Ruslan R, Baba I, Leman AM, Wai TL. A framework of non-fatal occupational injury surveillance in palm oil mill - a proposed study. ARPN J Eng Appl Sci. 2016;11(11):7322-30.

17. Hussin FS, Jalaludin J. Original Article Association of $\mathrm{Pm} 10$ and $\mathrm{Pm} \mathrm{2}$. 5 Exposure With Respiratory Health of the Children Living Near Palm Oil Mill, Dengkil. Malaysian J Public Heal Med 2016. 2016;16(Suppl. 2):20-6.

18. Roya LN, Shamsul B. HMT. The Association between Noise Exposure Level and Occupational Stress. Asian J Med Pharm Res. 2014;4(2):91-6.

19. Probst TM, Graso M. Pressure to produce=pressure to reduce accident reporting? Accid Anal Prev [Internet]. 2013 Oct [cited 2015 Apr 19];59:580-7. Available from: http://www.sciencedirect.com/science/ article/pii/S0001457513002881

20. Lipscomb HJ, Schoenfisch AL, Cameron W. Non-reporting of work injuries and aspects of jobsite safety climate and behavioral-based safety elements among carpenters in Washington state. Am J Ind Med. 2015;58:411-21.

21. Tucker S, Diekrager D, Turner N, Kelloway EK. Work-related injury underreporting among young workers: prevalence, gender differences, and explanations for underreporting. J Safety Res [Internet]. 2014 Sep [cited 2015 Apr 17];50:67-73. Available from: http://www.sciencedirect.com/science/ article/pii/S0022437514000449

22. Omulo E. Evaluation of the trends and patterns of reporting injuries in construction sites. A case study of Kasarani constituency [Internet]. University of Nairobi; 2016. Available from:

http://erepository.uonbi.ac.ke/bitstrea m/handle/11295/97243/Omulo_Evaluati on of the trends and patterns of reporting injuries in construction sites.. pdf?sequence $=1$ \&isAllowed $=y$

23. Pransky G, Snyder $T$, Dembe A, Himmelstein J. Under-reporting of workrelated disorders in the workplace: a case study and review of the literature. Ergonomics [Internet]. 1999;42(1):17182. Available from: http://www.tandfonline.com/doi/pdf/1 $0.1080 / 001401399185874$

24. Reid A, Lenguerrand E, Santos I, et al. Taking risks and survival jobs: Foreignborn workers and work-related injuries in Australia. Saf Sci [Internet]. 2014 Dec [cited 2015 Apr 17];70:378-86. Available from:

http://www.sciencedirect.com/science/ article/pii/S0925753514001611

25. Probst TM, Brubaker TL, Barsotti A. Organizational injury rate underreporting: The moderating effect of organizational safety climate. J Appl Psychol [Internet]. 2008;93(5):1147-54. Available from: http: / /0search.ebscohost.com.catalog.li brary.colostate.edu/login. aspx?direct $=\mathrm{tr}$ ue\&AuthType=cookie, ip, url,cpid\&custid= s4640792

$\& d b=$ syhref\&AN=JAP.IC.AADG.PROBST.O IRUME\&site=ehost -

live\%5Cnpapers3://publication/doi/10.1 037/0021-9010.93.5.1147

26. Probst TM, Barbaranelli C, Petitta L. The relationship between job insecurity and accident under- reporting: A test in two countries. Work Stress. 2013;27(4):383402.

27. Petitta L, Probst TM, Barbaranelli C. 
Safety Culture, Moral Disengagement , and Accident Underreporting. J Bus Ethics. 2017;141(3):489-504.

28. Janssen O, Gao L. Supervisory responsiveness and employee selfperceived status and voice behavior. $J$ Manage [Internet]. 2013;41(7):1-19. Available from: http: / /jom.sagepub.com/cgi/doi/10.117 7/0149206312471386

29. Probst TM, Estrada AX. Accident underreporting among employees: Testing the moderating influence of psychological safety climate and supervisor enforcement of safety practices. Accid Anal Prev [Internet]. 2010;42(5):1438-44. Available from: http: / /dx.doi.org/10.1016/j.aap.2009.0 6.027

30. Probst TM. Organizational Safety Climate and Supervisor Safety Enforcement: Multilevel Explorations of the Causes of Accident Underreporting. J Appl Psychol. 2015;

31. Koo TH, Surienty L, Hung DKM. Occupational Safety and Health ( OSH ) in Malaysian Small and Medium Enterprise ( SME ) and Effective Safety Management Practices. Int J Bus Technoprenuersh. 2011;1(2):322-38.

32. News L. Lee Lam Thye: Underreporting hinders efforts to tackle industrial accidents. The Star Online [Internet]. 2017 Jun 27;1-7. Available from: http:/ /www.thestar.com.my/news/natio $\mathrm{n} / 2017 / 06 / 27 /$ lee-lam-thyeunderreporting-hinders-efforts-to-tackleindustrial-accidents/

33. Lee C. Exploring the Characteristics of Organizational Factors on Safety Climate in Taiwan. Appl Mech Mater [Internet]. 2011;58-60:662-7. Available from: http://dx.doi.org/10.4028/www.scientifi c.net/AMM.58-60.662

34. Kaynak R, Toklu AT, Elci M, Toklu IT. Effects of Occupational Health and Safety Practices on Organizational Commitment , Work Alienation, and Job Performance: Using the PLS-SEM Approach. Int J Bus Manag. 2016;11(5):147-66.

35. Chae H, Min K, Park J, Kim K, Kim H, Lee K. Estimated rate of agricultural injury: the Korean Farmers ' Occupational Disease and Injury Survey. Ann Occup Environ Med 2014. 2014;26(8):1-7.

36. Zheng L, Zhao N, Chen D, et al. Nonfatal work-related injuries among agricultural machinery operators in northern China: a cross-sectional study. Injury [Internet]. 2014 Mar [cited 2015 Apr 17];45(3):599604. Available from: http://www.sciencedirect.com/science/ article/pii/S0020138313003112

37. Turner N, Tucker S, Kelloway EK. Prevalence and demographic differences in microaccidents and safety behaviors among young workers in Canada. J Safety Res [Internet]. 2015 Jun [cited $2015 \mathrm{Apr}$ 27];53:39-43. Available from: http: / /www.sciencedirect.com/science/ article/pii/S002243751500016X

38. Awang Z, Afthanorhan A, Mamat M. The Likert scale analysis using parametric based Structural Equation Modeling ( SEM ). Comput Methods Soc Sci. 2015;4(1):1321.

39. Awang Z. Research Methodology and Data Analysis. 2nd ed. Selangor, Malaysia: Penerbit Press UiTM; 2014. 321 p.

40. Hayes BE, Perander J, Smecko T, Trask J. Measuring Perceptions of Workplace Safety: Development and Validation of the Work Safety Scale. 1998;29(3):14561.

41. Tucker S, Chmiel N, Turner N, Sandy Hershcovis $M$, Stride CB. Perceived organizational support for safety and employee safety voice: The mediating role of coworker support for safety. $J$ Occup Health Psychol. 2008;13(4):31930.

42. Zin SM, Ismail F. Employers' Behavioural Safety Compliance Factors toward Occupational, Safety and Health Improvement in the Construction Industry. Procedia - Soc Behav Sci [Internet]. 2012 [cited 2015 Mar 11];36:742-51. Available from: http://www.sciencedirect.com/science/ article/pii/S1877042812005484

43. Kouabenan DR, Ngueutsa R, Mbaye S. Safety climate, perceived risk, and involvement in safety management. Saf Sci [Internet]. 2015 Aug [cited 2015 Apr 12];77:72-9. Available from: http: / /www.sciencedirect.com/science/ article/pii/S0925753515000673 